\title{
Opinion
}

\section{The Neurochemistry of Autism}

\author{
Rosa Marotta ${ }^{1}{ }^{1}$, Maria C. Risoleo ${ }^{1,2}$, Giovanni Messina ${ }^{3}\left[\right.$, Lucia Parisi ${ }^{4,+}$,

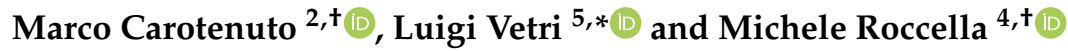

1 Department of Medical and Surgical Sciences, University "Magna Graecia", Catanzaro 88100, Italy; marotta@unicz.it (R.M.); mariacristinarisoleo@yahoo.it (M.C.R.)

2 Clinic of Child and Adolescent Neuropsychiatry, Department of Mental Health, Physical and Preventive Medicine, University of Campania “Luigi Vanvitelli”, Napoli 80138, Italy; marco.carotenuto@unicampania.it

3 Department of Clinical and Experimental Medicine, University of Foggia, Foggia 71100, Italy; giovanni.messina@unifg.it

4 Department of Psychology, Educational and Science and Human Movement, University of Palermo, Palermo 90128, Italy; lucia.parisi@unipa.it (L.P.); michele.roccella@unipa.it (M.R.)

5 Department of Sciences for Health Promotion and Mother and Child Care "G. D'Alessandro", University of Palermo, Palermo 90127, Italy

* Correspondence: luigi.vetri@you.unipa.it or luigi.vetri@gmail.com; Tel.: +39-3286434126

+ Interuniversity group for study and research on Neurodevelopmental Disorders in Children and Adolescents.

Received: 20 February 2020; Accepted: 10 March 2020; Published: 13 March 2020

check for updates

\begin{abstract}
Autism spectrum disorder (ASD) refers to complex neurobehavioral and neurodevelopmental conditions characterized by impaired social interaction and communication, restricted and repetitive patterns of behavior or interests, and altered sensory processing. Environmental, immunological, genetic, and epigenetic factors are implicated in the pathophysiology of autism and provoke the occurrence of neuroanatomical and neurochemical events relatively early in the development of the central nervous system. Many neurochemical pathways are involved in determining ASD; however, how these complex networks interact and cause the onset of the core symptoms of autism remains unclear. Further studies on neurochemical alterations in autism are necessary to clarify the early neurodevelopmental variations behind the enormous heterogeneity of autism spectrum disorder, and therefore lead to new approaches for the treatment and prevention of autism. In this review, we aim to delineate the state-of-the-art main research findings about the neurochemical alterations in autism etiology, and focuses on gamma aminobutyric acid (GABA) and glutamate, serotonin, dopamine, $\mathrm{N}$-acetyl aspartate, oxytocin and arginine-vasopressin, melatonin, vitamin $\mathrm{D}$, orexin, endogenous opioids, and acetylcholine. We also aim to suggest a possible related therapeutic approach that could improve the quality of ASD interventions. Over one hundred references were collected through electronic database searching in Medline and EMBASE (Ovid), Scopus (Elsevier), ERIC (Proquest), PubMed, and the Web of Science (ISI).
\end{abstract}

Keywords: autism spectrum disorder; neurochemistry; GABA; glutamate; serotonin; dopamine; acetylcholine; N-acetyl aspartate; oxytocin; melatonin

\section{Introduction}

Autism spectrum disorder (ASD) refers to complex neurobehavioral and neurodevelopmental conditions characterized by impaired social interaction and communication, restricted and repetitive patterns of behavior or interests, and altered sensory processing [1]. The prevalence of autism has significantly increased during the last two decades from two to five per 10,000 children to 1:59 children (one in 37 boys and one in 151 girls), and the prevalence in males is four times greater than females [2]. 
Increasing evidence underlines the biological basis of autism. In fact, onset symptoms are observed before three years of age and, in most cases, changes in social behavior or other slight autistic features are noticed in the first few months of life [3]. This suggests that behind the pathophysiology of autism there are neuroanatomical and neurochemical events occurring relatively early in the development of the central nervous system (CNS). Numerous studies have also shown that autism can often be comorbid with other neurological and psychiatric disorders, such as global development delay and cognitive deficits, epilepsy or electroencephalographic (EEG) anomalies, sleep disorders, developmental coordination disorder, neuropathies, Tourette syndrome, anxiety, oppositional defiant disorder, conduct disorder, attention deficit hyperactivity disorder (ADHD), mood disorders, psychosis, personality disorder, post-traumatic stress disorder, eating disorders, gender dysphoria, and substance abuse $[4,5]$. Moreover, there are several medical conditions comorbid to autism such as immunological disorders, gastrointestinal diseases, sleep-related breathing disorders, and there are several genetic syndromes commonly associated with autism (fragile X syndrome, Rett syndrome, Angelman syndrome, tuberous sclerosis complex, Phelan McDermid syndrome, Timothy syndrome, neurofibromatosis type 1 , etc.) [6-8].

All these factors contribute to a phenotypic heterogeneity that necessarily reflects a complex multifactorial etiology of ASD. This has led most researchers to consider autism dimensionally rather than using a categorial approach.

To a large extent, the ASD etiopathogenesis is unknown. It is a multifactorial condition caused by both genetic and environmental factors. Moreover, it has become clear that autism has an important genetic component. Siblings of individuals with autism have a prevalence of $2.9 \%$ to $3.7 \%$, which represents a nearly 100-fold increased risk as compared with the general population $[9,10]$. Twin studies have found concordance rates of $36 \%$ to $91 \%$ between monozygotic twins, and concordance rates of $1 \%$ between dizygotic twins [11].

The first data about the involvement of neurotransmission in autism were obtained several decades ago with studies on postmortem brain and measurements of bodily fluids, and, more recently, through molecular imaging and genetic evidence about neurotransmitters.

Neurotransmitters and neuropeptides play a fundamental role in normal brain development and contribute to memory, behavior, and motor activity regulation [12]. Indeed, they influence neuronal cell migration, differentiation, synaptogenesis, apoptosis, and synaptic pruning. Therefore, a neurotransmitter system dysfunction can lead to impairments in the processes of brain development, determining autism [13].

This review focuses on evidence that suggests a role for neurotransmission dysregulation in autism and how these alterations could be useful for pharmacologic intervention in autism or as precocious biomarkers.

\section{Aims and Methods}

All of the aforementioned reasons have led researchers to rethink their efforts to understand the neurochemical alterations underlying ASD. The aim of the current review was to collect an overview of original articles about the contribution of neurotransmitters and neuropeptides to the pathophysiology of autism with a focus on gamma aminobutyric acid (GABA) and glutamate, serotonin, dopamine, $\mathrm{N}$-acetyl aspartate, oxytocin and arginine-vasopressin, melatonin, vitamin $\mathrm{D}$, orexin, endogenous opioids, and acetylcholine.

This review helps to better delineate the state-of-the-art main research findings about the neurochemical alterations in autism etiology and suggests possible related therapeutic approaches that could improve the quality of ASD interventions.

To this end, over one hundred articles, published over the years, were reviewed by performing a search using the following syntax (autism or autism spectrum disorder or Asperger syndrome or pervasive developmental disorders (Title/Abstract)) and (GABA or glutamate or serotonin or dopamine or $\mathrm{N}$-acetyl aspartate or oxytocin or arginine-vasopressin or melatonin or vitamin $\mathrm{D}$ or orexin or 
opioids or acetylcholine (Title/Abstract)). References were identified through electronic database searching in Medline (Ovid, 1946 to present) and EMBASE (Ovid), and they were adapted for Scopus (Elsevier), ERIC (Proquest), PubMed, and the Web of Science (ISI). The final database search was run on February 2020.

\section{Gamma Aminobutyric Acid}

Gamma aminobutyric acid (GABA) is derived from glutamate thanks to the action of glutamate decarboxylase and it has a complex and homeostatic relationship balancing neuronal excitability. In immature brains, GABA receptors are different from those of adult brains. GABA represents the main excitatory neurotransmitter during brain development, and it influences proliferation, migration, synapse maturation, differentiation, and cell death [14].

Alterations in gabaminergic and glutaminergic systems cause a disrupted excitatory/inhibitory balance and are also potential mechanisms for autistic behaviors and for various neurodevelopmental disorders.

The excitatory/inhibitory imbalance theory for social behavior impairments has been demonstrated through the depolarization of cells for a long period of time in mice medial prefrontal cortex. The elevation of excitatory/inhibitory balance provokes a deep impairment in information processing and social behavior dysfunction [15].

A magnetic resonance spectroscopy study has shown a reduced glutamate concentration in the striatum as compared with controls both in adults with idiopathic ASD and in mice models, especially in mutational model of SHANK3 and neuroligin-neurexin complex [16]. Similarly, reductions in GABA have been detected in magnetic resonance spectroscopy studies in subjects in an age-dependent manner, in motor, visual, auditory, somatosensory area, and in the perisylvian region of the left hemisphere, leading to abnormal information processing [17,18].

The plasma GABA and glutamate levels are altered in children with ASD. In particular, there is a significant elevation of plasma GABA and the glutamate/glutamine ratio while the levels of plasma glutamine and glutamate/GABA ratios are significantly lower as compared with the controls [19]. This imbalance between excitatory and inhibitory mechanisms in the GABA and glutamate neurophysiology has been linked to other neurodevelopmental disorders such as global developmental delay and mental retardation, schizophrenia, and epilepsy [20,21].

Atypical sensory perceptions are very common in ASD. Using magnetic resonance imaging (MRI) spectroscopy, Robertson et al. demonstrated a tight linkage between atypical dynamics of binocular rivalry in ASD and reduced GABAergic, but conserved glutamatergic levels, in the autistic occipital visual cortex [22].

MECP2 mutations provoke Rett syndrome and several neuropsychiatric disorders including autistic symptoms. Mutations in MeCP2 gene lead to a GABAergic dysfunction through reduced glutamic acid decarboxylase- 1 and -2 levels and GABA immunoreactivity, changing the synaptic physiology and provoking numerous Rett syndrome and autistic-like characteristics, including repetitive behaviors in mice [23].

Some studies underlined an association between single-nucleotide polymorphisms (SNPs) of GABA receptors located in the chromosome 15q11-q13 of ASD subjects [24,25]. However, a recent meta-analysis has demonstrated that different SNPs of GABA receptor subunits B3, A5, and G3 had no correlations with autism in different ethnic populations [26].

The pharmacological approach with GABA modulators in autism aims to target the imbalance between excitatory glutamatergic and inhibitory GABAergic pathways. Arbaclofen, acamprosate, bumetanide, and valproate are the most studied substances. However, the majority of these studies are open-label trials and imply little statistical significance. A systematic review has, therefore, remarked that, to date, there is lack of evidence suggesting the use of GABA modulators to treat autism core symptoms, and further well-designed trials are needed [27]. 


\section{Glutamate}

Glutamate is the main excitatory neurotransmitter in the mammalian cortex. There are three main classes of receptors for glutamate, known as N-methyl-D-aspartate receptors (NMDARs), $\alpha$-amino-3-hydroxy-5-methyl-4-isoxazolepropionic acid receptors (AMPARs), and metabotropic glutamate receptors [28]. Both NMDARs and AMPARs have also been implicated in ASD and much evidence supports this hypothesis [29].

Valproic acid-induced rodent models of autism have shown a selective overexpression of NR2A and NR2B subunits of NMDA receptors. This overexpression provoked enhanced NMDA receptor-mediated synaptic currents which led to an amplified postsynaptic plasticity in neocortical pyramidal neurons [30].

Modifications of AMPAR GluA2 subunit have deep effects on neuronal excitability and GluA2 dysregulation has been linked to different neuropsychiatric disorders such as intellectual disability and Rett syndrome [31]. Moreover, in a mouse model of CDKL5 deficiency disorder showing a phenotype characterized by autistic-like behaviors, intellectual disability, and seizures, a significant decrease in AMPAR GluA2 subunit in the hippocampus has been documented [32].

NMDA and NMDAR have also been correlated to autism. Specifically, mutations of GRIN2A and GRIN2B genes (respectively coding for GluN2A and GluN2B subunits) have been linked to ASD [33,34].

An alteration of NMDAR has been highlighted in several mouse models of autism such as Shank3 DC/DC mice, neuroligin-3 R451C knock-in mice, Fmr1-/- mice, and Shank2-/- mice [35,36].

Recent theories support the involvement of the cerebellum in ASD. Interestingly, for the first time, alterations have been demonstrated in the cerebellum granular layer of IB2 (islet brain-2) $\mathrm{KO}$ mouse models. The IB2 gene is implicated in Phelan-McDermid syndrome and provokes autistic symptoms and a severe motor delay. The IB2 KO mouse models have a NMDA receptor hyperactivity and hyperplasticity that determines an increase of excitatory/inhibitory balance and an enhanced long-term potentiation in mossy fiber and granule cells [37].

Nevertheless, an early correction of NMDAR dysfunction showed, in mouse models, a significant improvement in autistic-like behaviors [38-40].

Evidence shows that mutations in genes (SHANK, NLGN3, NLGN4, and UBE3A) involved in synapse formation and maintenance and in protein targeting are correlated both to the development of autistic traits and to glutamatergic dysregulation [41-43].

However, a large glutamatergic and GABAergic gene set analysis in subjects with ADHD and autism has shown only a significant association between glutamate gene set and hyperactivity and impulsivity symptom severity. No significant associations were found for autism symptoms in glutamate and GABA gene set which reinforces the need for further research on the genetics of excitatory/inhibitory imbalance in ASD [44].

In human beings, pharmacological enhancement or suppression of NMDAR function has determined an improvement in ASD symptoms [45]. In particular, an NMDAR agonist (D-cycloserine) significantly reduced social withdrawal and repetitive behavior [46,47]. Similarly, the administration of an NMDAR antagonist (memantine) improved stereotypies, lethargy, irritability, hyperactivity, and inattention suggesting a bidirectional NMDAR dysfunction [48,49].

\section{Serotonin}

Several studies have shown the involvement of the serotonin system in the etiology of autism during early brain development [50]. Serotonin (5-hydroxytryptamine, 5-HT) is a neurotransmitter belonging to the monoamine family; it is involved in the modulation of several developmental events, including cell division, cortical proliferation, migration, differentiation, cortical plasticity, and synaptogenesis [51,52]. Serotonin intervenes in various brain functions such as memory, learning ability, and has a role as a sleep and mood modulator [53,54]. Studies have revealed that the serotonin transporter (SERT or 5-HTT) or serotonin levels were higher in autistic children and in animal models as compared with controls, while there was postmortem evidence for reductions in both 5-HT2A 
and 5-HT1A binding in ASD brain [55-57]. Positron emission tomography (PET) studies revealed that healthy children between two and five years of age showed an elevated 5-HT synthesis, with a subsequent decline at puberty. Children with autism did not show this decline in the ability to synthesize serotonin over time, and the levels were significantly lower in these children at the age of two to five as compared with the controls, slightly increasing with age [58,59].

Polymorphisms in the SLC6A4 gene, which encodes for platelet and neuronal transport of 5-HT, have been associated with autism. These polymorphisms are functionally significant, and the higher 5-HT levels observed in ASD are substantial in children with SLC6A4 polymorphisms [60,61]. Differentially, there is animal evidence that embryos developing in Slc6a $4^{+/-}$dams have reduced resilience to prenatal stress which increases the offspring's risk of developing ASD-like characteristics [62].

Several studies have detected platelet hyperserotonemia in ASD subjects with average increases of $20 \%$ to $50 \%$ [63-65]. Interestingly, this increase appeared to be specific to autism or ASD because it was not observed in intellectual disability or in other neuropsychiatric disorders [66,67].

Some selective serotonin reuptake inhibitors (SSRIs) have shown modest efficacy in the treatment of specific behaviors such as disruptive and repetitive symptoms; however, only fluoxetine has shown good evidence of decreasing global autism symptomatology $[68,69]$.

All these studies confirm the role of serotonin in the pathophysiology of autism. However, the mechanism of elevation remains uncertain and the relationship with central serotonergic functioning needs further investigations.

\section{Dopamine}

In addition to being correlated to motor control, dopamine plays an important role in social cognition and behaviors especially through the mesocorticolimbic pathway [70].

Numerous studies have suggested that ASD could be linked to dopaminergic dysfunction and have hypothesized that dopamine imbalances in specific brain regions could lead to autistic behaviors [71]. In particular, autistic subjects have shown alterations in the mesocorticolimbic dopaminergic signaling pathway, such as reduced dopamine release in the prefrontal cortex and reduced neural response in the nucleus accumbens [72,73]. An article suggested that, in autism, social deficits were determined by a dysfunction of the mesocorticolimbic circuit, while the dysfunction of the nigrostriatal circuit led to stereotyped behaviors [74]. Concerning the nigrostriatal dopaminergic circuit, studies on mouse models have shown that drug-induced nigrostriatal pathway dysfunction caused stereotyped behaviors in mice [75]. Indeed, the administration of D1 dopaminergic receptor antagonists have reduced these behaviors [76].

A recent study supported the hypothesis that mesocorticolimbic circuit could impact social behaviors through the bidirectional control of dopaminergic projections from ventral tegmental area to nucleus accumbens. In particular, the optogenetic stimulation of dopaminergic ventral tegmental area neurons determined the activation of D1 receptors leading to an increase in the time that animals spent in social interaction, whereas inhibition had the opposite effect [77].

Genetic studies have shown an association between autism and several gene polymorphisms involved in dopaminergic pathways, such as dopamine receptors DR3 and DR4, or dopamine transporter (DAT) [78-80]. A recent study on mouse models highlighted that mutations in DAT provoked anomalous dopamine efflux and led to autistic-like behavioral phenotypes [81]. Dopaminergic gene polymorphisms should modulate emotion dysregulation and ADHD symptoms in children with ASD [82]. Moreover, haploinsufficiency of SHANK3 have reduced neuronal dopaminergic activity in the ventral tegmental area generating behavioral anomalies including impaired social skills [83].

Only the dopamine receptor blockers (risperidone and aripiprazole) are EMA/FDA-approved for the treatment of irritability, and they have also been shown to be effective in treating ASD repetitive behaviors $[84,85]$.

All this evidence should lead to considering the administration of dopamine modulators as a therapeutic target for further studies in ASD behavioral treatment. 


\section{Acetylcholine}

Acetylcholine is the neurotransmitter used by motor neurons at the neuromuscular junction. It is also the main neurotransmitter of the parasympathetic nervous system and acts as a neurotransmitter and a neuromodulator in the CNS.

The main evidence of cholinergic system abnormalities in ASD has included a significant reduction of nicotinic $\alpha 4 \beta 2$ subtype of ACh receptors (nAChRs) in the parietal and frontal cortex detected in post-mortem brain samples $[86,87]$.

Another study has shown a reduction of cerebellar $\alpha 4 \mathrm{nAChRs}$ which could be linked to the loss of Purkinje cells and to a compensatory increase in $\alpha 7 \mathrm{nAChRs} \mathrm{[88].}$

Several studies on ASD animal models have shown the involvement of nAChRs in modulating social and repetitive behaviors [89].

There is animal evidence that $\alpha 4 \beta 2$ nAChRs are linked to autistic-like symptoms and the administration of ABT-418 (a neuronal nicotinic acetylcholine receptor agonist) determines a statistically significant improvement in these psychiatric symptoms [90].

Alpha4 nAChR subunit knock-out and beta2 nAChR subunit knock-out mice, respectively, show increases of anxiety and abnormal sleep pattern [91,92].

The $\alpha 7$ nicotinic receptor plays a particularly promising role in the pathogenesis of neuropsychiatric pathologies, including schizophrenia, ASD, ADHD, addictive disorders, because it is involved in sensory processing, cognition, working memory, attention and it is highly expressed in the regions involved in these cognitive functions such as hippocampus and frontal cortex $[93,94]$.

Growing evidence supports the idea that the stimulation of $\alpha 7 \mathrm{nAChR}$ receptor has procognitive effects both in animal and in vivo models. These effects are mediated by PI3K/Akt signaling cascade crosstalk with the Wnt/-catenin signalling cascade and both transcriptional and non-transcriptional effects of catenin, metabolic effects of transient increases in the intraneuronal concentration of $\mathrm{Ca}^{2+}$, and changes in membrane potential [95].

Mutations involving the CHRNA7 gene in the chromosome region 15q13.3 have been correlated to autistic-like phenotypes [96]. In CHRNA7 null mutant mice, an increase of IL6 has been observed in mutant fetal brain due to maternal immune activation, and increased behavioral deficits in the offspring have also been observed. Moreover, it has been reported that the gestational choline supplementation improved the fetal brain's response to maternal immune activation and prevented several induced behavioral abnormalities in the offspring [97].

Alpha7 and $\alpha 4 \beta 2$ subtypes of nAChRs are highly expressed in the CNS and, as we have observed, they are more involved in the ASD pathogenesis. Therefore, they have been detected as a possible therapeutic target.

A randomized, double-blind, placebo-controlled trial on galantamine showed a statistical improvement in irritability, lethargy, and social withdrawal with good tolerability [98].

Evidence on animal models and on men has also demonstrated that donepezil has a good safety and tolerability profile and determined an improvement in behavioral dysfunctions [99].

3-(2,4-Dimethoxybenzylidene)-anabaseine (DMXB-A) is a selective partial agonist for $\alpha 7$ - nAChRs and has shown its efficacy in a randomized, double-blind crossover trial on neurocognitive improvements in subjects with schizophrenia [100]. Analogous effects have been highlighted in two adult patients with ASD [101].

\section{N-acetyl Aspartate}

$\mathrm{N}$-acetyl aspartate (NAA) is a widely diffuse metabolite in the human CNS. Its high brain concentration and its main functions remain uncertain. It is expressed in neurons, oligodendrocytes, and myelin and it is synthesized in the mitochondria derived from aspartic acid [102]. A decreased NAA concentration has been found in several psychiatric disorders and seemed to be correlated to a mitochondrial dysfunction [103]. The altered metabolic state can be reversed with psychopharmacological treatment capable of restoring a normal NAA level [104]. 
A functional MRI study has shown a significant reduction of NAA concentration in all brain regions and a specific reduction in the left frontal cortex as compared with the controls [105]. Another study showed the relationship between the dorsal striatal volume and NAA and glutamate levels in ASD and in obsessive-compulsive disorder as compared with the controls, underlying possible overlapping subcortical abnormalities [106]. Further studies are needed to elucidate the exact role of NAA in the pathogenesis of ASD.

\section{Oxytocin and Arginine-Vasopressin}

In recent years, researchers have shown an increasing interest in oxytocin (OXT), another molecule that seems to be involved in the neurochemistry of autism. Arginine-vasopressin (AVP) belongs to the same superfamily as oxytocin. Their structure is very similar, and their genes are close on chromosome 20p13, separated only by $12 \mathrm{~kb}$ of DNA, and they have an opposite transcriptional orientation. For these reasons, two neuropeptides influencing one another's functions have effects on the same neural structures in the central and autonomic nervous systems and they both modulate human behavior [107].

Oxytocin is a neuropeptide involved in a number of physiological processes, including parturition and lactation. It has been shown to modify synaptic plasticity and to modulate social behaviors such as eye contact, social recognition, aggressivity, sociosexual behaviors with a role in sculpting emotional and social "self" [108,109].

Altered plasma levels of OXT and AVP have been reported in autistic individuals and they are often correlated to aberrant functional connectivity $[110,111]$. An association between the degree of methylation of the oxytocin receptor (OXTR) gene and autistic symptoms has been reported $[112,113]$. However, the results are not all consistent.

The genetics of OXT and AVP receptors has been widely explored. In particular, two microsatellites, RS1 and RS3, within the promoter region of vasopressin receptor 1A (V1AR), and rs28632197 and rs35369693 SNPs of vasopressin V1b receptor (V1BR), have been found to be significantly linked to ASD. Two SNPs of the OXT receptor gene (rs53576 and rs225429) are also significantly associated with ASD. However, the mechanisms whereby these polymorphisms contribute to ASD pathogenesis have yet to be completely clarified [114,115].

Interestingly, mutations in SHANK3 (a postsynaptic scaffolding protein implicated in synapse development and ASDs) [116] have effects on the oxytocinergic system and this alteration could be the cause of some behavioral phenotypes related to synaptic plasticity in autism [117]. Recently, it has been hypothesized that the failure of the oxytocinergic system during the early stages of neurodevelopment could affect social behavior by altering synaptic activity and plasticity [118].

Animal model research has documented that the administration of OXT and AVP was able to rescue autistic traits and increase social skills [119-121]. In humans, there is some evidence that the administration of oxytocin reduces some dysfunctional behaviors associated with autism, especially social skills, repetitive behaviors, anxiety, irritability, and self-injurious behaviors [122-124]. However, a recent meta-analysis that reviewed randomized controlled trials on ASD symptomatology did reveal that there was no benefit of oxytocin over placebo and provided further proof to support existing evidence [125].

In the end, there is evidence for crucial interaction between the dopaminergic, AXT-AVP, and serotoninergic systems in different areas of social brain with great influence on human social behavior [126].

\section{Melatonin}

Children with ASD often have sleep disorders, such as difficulty falling and staying asleep, and parasomnia $[127,128]$. Melatonin is a major regulator of the sleep-wake rhythm, reduces sleep latency, it is a powerful antioxidant, it has a role in neurodevelopment and plasticity, and it can be important in placental homeostasis [129] and immunity [130]. Studies involving autistic individuals show 
lower melatonin or melatonin metabolite plasma levels and lower urinary melatonin sulfate excretion rates [131]. Moreover, a recent research showed that 6-sulfatoxymelatonin levels were significantly lower in mothers with an ASD child than in the controls [132]. During pregnancy, melatonin is able to cross the placenta providing photoperiodic information to the fetus and establishing a normal sleep cycle which is essential for normal neurodevelopment. Indeed, maternal melatonin, before the maturation of the fetal pineal gland, protects against brain inflammation and injury [133].

Some studies underline that specific gene abnormalities (MTNR1A, MTNR1B, GPR50, and ASMT) could contribute to reduced melatonin level or to altered melatonin receptor function or they could be involved in melatonin synthesis in a small percentage of ASD patients. [134]

The use of melatonin for the treatment of chronic sleep-wake cycle disorders in children with autism is constantly increasing [135]. Melatonin, associated with educational and behavioral interventions, appears to be the most effective treatment for improving both sleep problems and daytime behaviors [136]. Indeed, its effects go beyond sleep, melatonin acts on anxiety, depression, pain and gastrointestinal dysfunctions, improving the well-being of ASD subjects [137].

\section{Vitamin D}

Vitamin D is an active steroid with an important role in antioxidant activity, neuronal calcium regulation, immunomodulation, and in the regulation of neurotransmitters and neurotrophic factors [138]. In the brain, vitamin D also plays a role in neuronal proliferation and in synaptic plasticity [139]. Lower levels of vitamin D have been reported in autistic individuals [140,141]. There is animal evidence that a partial lack of vitamin $\mathrm{D}$ exposes the brain to neuroinflammation and that the exogenous supplementation has a protective effect ameliorating neurotoxicity, inflammation, and DNA damage [142]. Vitamin D has an important role in neurotransmission. In fact, it regulates glutamate, GABA, serotonin, dopamine, and it alters immune function relevant in ASD pathogenesis and causes steroid and placental dysregulation [143].

Moreover, it seems that 25-hydroxyvitamin D deficiency either at mid-gestation or at birth is associated with an increase in autistic traits in children [144].

Exogenous vitamin D supplementation can have beneficial effects in ASD children and improve signs and symptoms of ASD [145,146], and the American Academy of Pediatrics recommends vitamin D supplementation during infancy and childhood [147]. However, a recent randomized placebo-controlled trial underlined that vitamin D supplementation had limited beneficial effects on children with ASD without any effect on the primary outcome [148].

\section{Orexin System}

Recently, the interest of researchers with respect to orexin related to autism has been increasing. Orexin, also known as hypocretin, is a neuropeptide secreted by neurons located in the lateral hypothalamus and perifornical areas. Orexergic fibers have great distribution in the brain and they have many physiological functions, such as excitement, sleep regulation, cognition, stress, appetite and metabolism [149]. Orexin dysfunction appears to be related to various neurological disorders including addiction, depression, anxiety, and schizophrenia [150]. Considering the prevalence of sleep disorders in individuals with ASD [114,151], it is possible to hypothesize that an alteration of the orexinergic system could be implicated in the pathogenesis of these disorders. Sleep disturbances in ASD patients depend on the increased orexinergic system activity (probably due to amygdala dysfunction) associated with a reduced serotoninergic and melatoninergic system activity [152,153]. In a recent study, plasma levels of Orexin A were higher in ASD patients than in the healthy population [146]. Another study underlined a strong correlation between plasma levels of oxytocin and orexin A in the ASD groups investigated. This finding supported the contribution of oxytocinergic mechanisms in ASD [154]. However, there are few studies in this field and the results are still contradictory. 


\section{Endogenous Opioids}

Endogenous opioids are peptides that act as neuromodulators in the CNS. There are three types of endogenous opioids, i.e., beta-endorphins, enkephalins and dynorphins. Opioid administration determines behavioral effects, such as insensitivity to pain, affective lability, stereotypical behavior, and reduced socialization $[155,156]$. Blood and liquor studies have shown that beta-endorphin levels are altered in subjects with ASD, although not all results have been concordant [157,158]. Interestingly, a study has shown elevated plasma levels of beta-endorphin in ASD individuals after venipuncture, suggesting a different mode of pain expression and a lower ability to regulate their emotional response [159].

Some studies have examined the effects of opioid antagonists (naloxone and naltrexone) in individuals with autism and a reduction in self-aggressive behavior, hyperactivity, restlessness, and withdrawal has been demonstrated $[160,161]$. However, a recent systematic review clarified that although opioids can improve hyperactivity and restlessness in ASD children, there was not sufficient evidence that they had an impact on the core symptoms of autism in the majority of participants. Nevertheless, a subgroup of children with autism and abnormal endorphin levels have responded to naltrexone [162].

\section{Discussion}

ASD is a complex neurobehavioral syndrome and no specific causes have yet been identified. Anatomical brain abnormalities, genetic anomalies, and neurochemical dysfunctions of various neurotransmitters and neuropeptides including GABA and glutamate, serotonin, dopamine, $\mathrm{N}$-acetyl aspartate, oxytocin, arginine-vasopressin, melatonin, vitamin D, orexin, opioids, and acetylcholine contribute to the onset of autism. Our review suggests the important role played by altered neurotransmission in the etiopathogenesis of ASD (see Table 1). It is clear that many pathways are involved in determining autism, but how these biological systems interact with each other remains obscure. Further neurochemical network studies on early neurodevelopment alterations are required. Advancing the understanding of the etiology of the ASD mechanisms represents a real challenge, mainly due to the enormous heterogeneity of ASD.

The evidence gathered by our review supports the existence of several dysregulated neurotransmitters and neuropeptides in animal models and in patients with autism. Although there is some evidence suggesting that specific receptor anomalies lead to specific phenotypic variations it is very hard to highlight the pathogenetic role of every neuronal receptor in determining the autism phenotype.

In this framework, some clinical features of ASD could, at least partially, find an explanation such as sensory integration alteration [163], and neuropsychological and psychological dysfunction [164-166].

The heterogeneity of autism makes it very difficult to detect exclusive neurobiological and genetic traits of ASD and, to date, there are only a very few replicated neurochemical findings.

Additional efforts are required to understand whether these anomalies have a primary etiological role or whether they are rather secondary epiphenomena of a global cerebral dysfunction. Most studies about autism etiology more fruitfully examine specific domains of behavior or single impairments rather than the whole autism phenotype.

Advances in research could lead to new therapeutic strategies that could be useful for improving and perhaps even preventing autism symptoms.

The growing body of evidence reported by our review on the pharmacological substances targeting receptor abnormalities often showed conflicting results and we hope that higher quality studies would be conducted in order to clarify what receptor system could represent an effective pharmacological target for the treatment of autism symptomatology.

In conclusion, additional evidence on the neurochemical alteration of autism is needed and a greater knowledge in this field could lead to a completely new approach to the pharmacological management of autism and to the identification of biomarkers with greater specificity and sensitivity. 
Table 1. Main neurochemical findings.

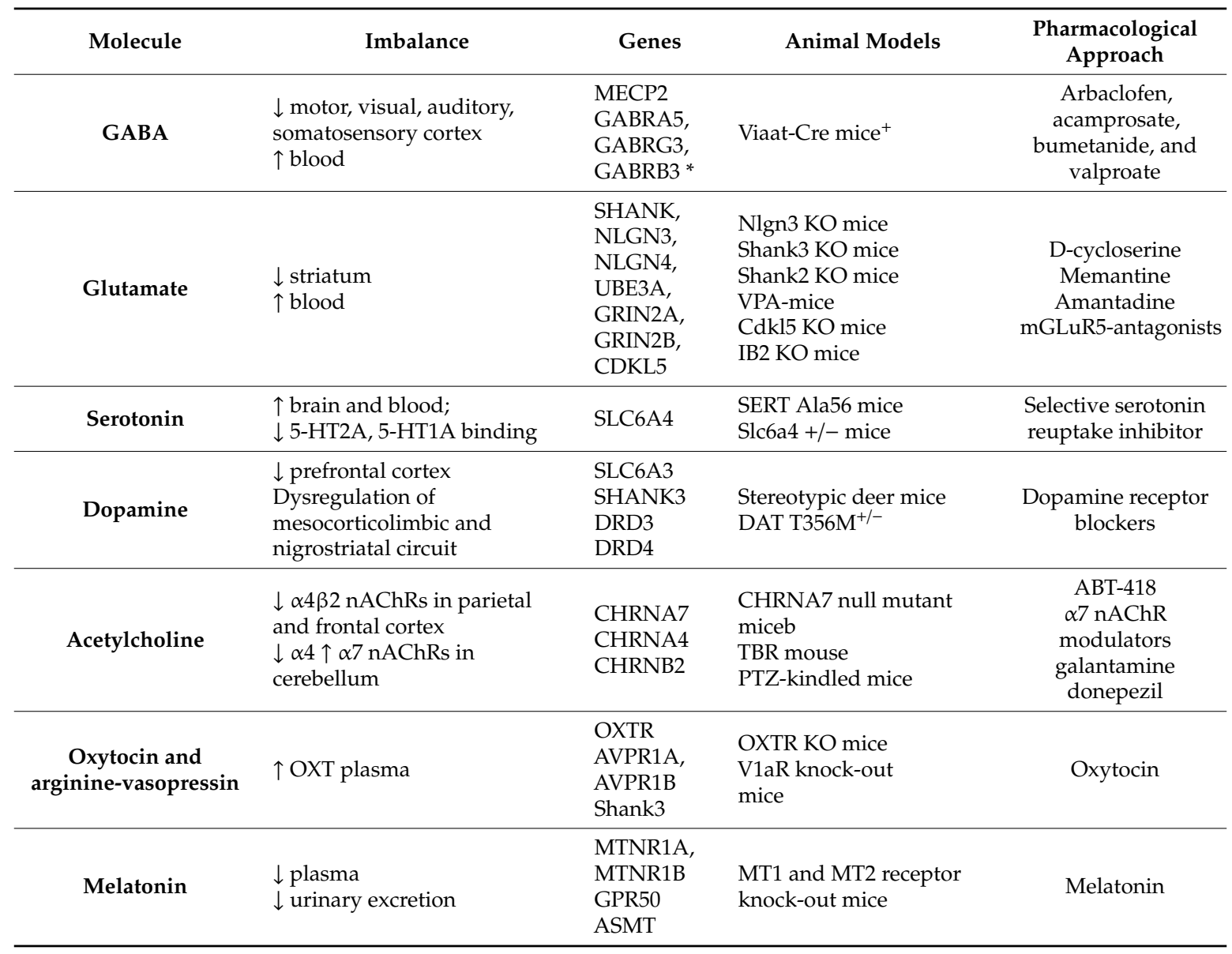

Author Contributions: Conceptualization, R.M., M.C. and M.R.; methodology, L.P., M.C.R., and G.M.; software, L.V. and L.P.; validation, M.R., M.C. and R.M.; formal analysis, M.C.R.; writing-original draft preparation, R.M. and L.V.; writing-review and editing, L.V. and R.M.; visualization, M.R.; supervision, M.R. and M.C.; funding acquisition, M.R. All authors have read and agreed to the published version of the manuscript.

Funding: This research received no external funding.

Conflicts of Interest: The authors declare that the research was conducted in the absence of any commercial or financial relationships that could be construed as a potential conflict of interest.

\section{References}

1. American Psychiatric Association. Diagnostic and Statistical Manual of Mental Disorders (DSM-5®); American Psychiatric Pub: Washington, DC, USA, 2013.

2. Baio, J.; Wiggins, L.; Christensen, D.L.; Maenner, M.J.; Daniels, J.; Warren, Z.; Kurzius-Spencer, M.; Zahorodny, W.; Robinson Rosenberg, C.; White, T.; et al. Prevalence of autism spectrum disorder among children aged 8 years-Autism and developmental disabilities monitoring network, 11 sites, United States, 2014. MMWR Surveill. Summ. 2018, 67, 1. [CrossRef] [PubMed]

3. Lord, C. Follow-up of two-year-olds referred for possible autism. J. Child Psychol. Psychiatry 1995, 36, 1365-1382. [CrossRef] [PubMed]

4. Mazzone, L.; Postorino, V.; Siracusano, M.; Riccioni, A.; Curatolo, P. The relationship between sleep problems, neurobiological alterations, core symptoms of autism spectrum disorder, and psychiatric comorbidities. J. Clin. Med. 2018, 7, 102. [CrossRef] [PubMed]

5. Rosen, T.E.; Mazefsky, C.A.; Vasa, R.A.; Lerner, M.D. Co-occurring psychiatric conditions in autism spectrum disorder. Int. Rev. Psychiatry 2018, 30, 40-61. [CrossRef] 
6. Mrowka, M.; Jöbges, M.; Berding, G.; Schimke, N.; Shing, M.; Odin, P. Computerized movement analysis and beta-CIT-SPECT in patients with restless legs syndrome. J. Neural Transm. 2005, 112, 693-701. [CrossRef]

7. Operto, F.F.; Precenzano, F.; Bitetti, I.; Lanzara, V.; Fontana, M.L.; Pastorino, G.M.G.; Carotenuto, M.; Pisani, F.; Polito, A.N.; Smirni, D.; et al. Emotional Intelligence in Children with Severe Sleep-Related Breathing Disorders. Behav. Neurol. 2019, 2019, 6530539. [CrossRef]

8. Smirni, D.; Carotenuto, M.; Precenzano, F.; Smirni, P.; Operto, F.F.; Marotta, R.; Roccella, M. Memory performances and personality traits in mothers of children with obstructive sleep apnea syndrome. Psychol. Res. Behav. Manag. 2019, 12, 481. [CrossRef]

9. Bailey, A.; Le Couteur, A.; Gottesman, I.; Bolton, P.; Simonoff, E.; Yuzda, E.; Rutter, M. Autism as a strongly genetic disorder: Evidence from a British twin study. Psychol. Med. 1995, 25, 63-77. [CrossRef]

10. Chaste, P.; Leboyer, M. Autism risk factors: Genes, environment, and gene-environment interactions. Dialogues Clin. Neurosci. 2012, 14, 281.

11. Steffenburg, S.; Gillberg, C.; Hellgren, L.; Andersson, L.; Gillberg, I.C.; Jakobsson, G.; Bohman, M. A twin study of autism in Denmark, Finland, Iceland, Norway and Sweden. J. Child Psychol. Psychiatry 1989, 30, 405-416. [CrossRef]

12. Quaak, I.; Brouns, M.R.; Van de Bor, M. The dynamics of autism spectrum disorders: How neurotoxic compounds and neurotransmitters interact. Int. J. Environ. Res. Public Health 2013, 10, 3384-3408. [CrossRef] [PubMed]

13. Arya, A.; Sindhwani, G. Autism: An early-onset neurodevelopmental disorder. Int. J. Pharm. Sci. Res. 2016, 7, 3567.

14. Owens, D.F.; Kriegstein, A.R. Is there more to GABA than synaptic inhibition? Nat. Rev. Neurosci. 2002, 3, 715-727. [CrossRef] [PubMed]

15. Yizhar, O.; Fenno, L.E.; Prigge, M.; Schneider, F.; Davidson, T.J.; O’Shea, D.J.; Sohal, V.S.; Goshen, I.; Finkelstein, J.; Paz, J.T.; et al. Neocortical excitation/inhibition balance in information processing and social dysfunction. Nature 2011, 477, 171-178. [CrossRef]

16. Horder, J.; Petrinovic, M.M.; Mendez, M.A.; Bruns, A.; Takumi, T.; Spooren, W.; Barker, G.J.; Künnecke, B.; Murphy, D.G. Glutamate and GABA in autism spectrum disorder-A translational magnetic resonance spectroscopy study in man and rodent models. Transl. Psychiatry 2018, 8, 1-11. [CrossRef]

17. Rojas, D.C.; Singel, D.; Steinmetz, S.; Hepburn, S.; Brown, M.S. Decreased left perisylvian GABA concentration in children with autism and unaffected siblings. Neuroimage 2014, 86, 28-34. [CrossRef]

18. Puts, N.A.; Wodka, E.L.; Harris, A.D.; Crocetti, D.; Tommerdahl, M.; Mostofsky, S.H.; Edden, R.A. Reduced GABA and altered somatosensory function in children with autism spectrum disorder. Autism Res. 2017, 10, 608-619. [CrossRef]

19. Al-Otaish, H.; Al-Ayadhi, L.; Bjørklund, G.; Chirumbolo, S.; Urbina, M.A.; El-Ansary, A. Relationship between absolute and relative ratios of glutamate, glutamine and GABA and severity of autism spectrum disorder. Metab. Brain Dis. 2018, 33, 843-854. [CrossRef]

20. Ford, T.C.; Nibbs, R.; Crewther, D.P. Glutamate/GABA+ ratio is associated with the psychosocial domain of autistic and schizotypal traits. PLoS ONE 2017, 12, e0181961. [CrossRef]

21. Ford, T.C.; Nibbs, R.; Crewther, D.P. Increased glutamate/GABA+ ratio in a shared autistic and schizotypal trait phenotype termed Social Disorganisation. NeuroImage Clin. 2017, 16, 125-131. [CrossRef]

22. Robertson, C.E.; Ratai, E.M.; Kanwisher, N. Reduced GABAergic action in the autistic brain. Curr. Biol. 2016, 26, 80-85. [CrossRef] [PubMed]

23. Chao, H.T.; Chen, H.; Samaco, R.C.; Xue, M.; Chahrour, M.; Yoo, J.; Neul, J.L.; Gong, S.; Lu, H.C.; Heintz, N.; et al. Dysfunction in GABA signalling mediates autism-like stereotypies and Rett syndrome phenotypes. Nature 2010, 468, 263-269. [CrossRef] [PubMed]

24. Buxbaum, J.D.; Silverman, J.M.; Smith, C.J.; Greenberg, D.A.; Kilifarski, M.; Reichert, J.; Cook, E.H., Jr.; Fang, Y.; Song, C.Y.; Vitale, R. Association between a GABRB3 polymorphism and autism. Mol. Psychiatry 2002, 7, 311-316. [CrossRef] [PubMed]

25. Kim, S.A.; Kim, J.H.; Park, M.; Cho, I.H.; Yoo, H.J. Association of GABRB3 polymorphisms with autism spectrum disorders in Korean trios. Neuropsychobiology 2006, 54, 160-165. [CrossRef] [PubMed]

26. Mahdavi, M.; Kheirollahi, M.; Riahi, R.; Khorvash, F.; Khorrami, M.; Mirsafaie, M. Meta-analysis of the association between GABA receptor polymorphisms and autism spectrum disorder (ASD). J. Mol. Neurosci. 2018, 65, 1-9. [CrossRef] 
27. Brondino, N.; Fusar-Poli, L.; Panisi, C.; Damiani, S.; Barale, F.; Politi, P. Pharmacological modulation of GABA function in autism spectrum disorders: A systematic review of human studies. J. Autism Dev. Disord. 2016, 46, 825-839. [CrossRef]

28. Petroff, O.A. Book review: GABA and glutamate in the human brain. Neuroscientist 2002, 8, 562-573. [CrossRef]

29. Essa, M.M.; Braidy, N.; Vijayan, K.R.; Subash, S.; Guillemin, G.J. Excitotoxicity in the pathogenesis of autism. Neurotox. Res. 2013, 23, 393-400. [CrossRef]

30. Rinaldi, T.; Kulangara, K.; Antoniello, K.; Markram, H. Elevated NMDA receptor levels and enhanced postsynaptic long-term potentiation induced by prenatal exposure to valproic acid. Proc. Natl. Acad. Sci. USA 2007, 104, 13501-13506. [CrossRef]

31. Li, W.; Xu, X.; Pozzo-Miller, L. Excitatory synapses are stronger in the hippocampus of Rett syndrome mice due to altered synaptic trafficking of AMPA-type glutamate receptors. Proc. Natl. Acad. Sci. USA 2016, 113, E1575-E1584. [CrossRef]

32. Yennawar, M.; White, R.S.; Jensen, F.E. AMPA receptor dysregulation and therapeutic interventions in a mouse model of CDKL5 Deficiency Disorder. J. Neurosci. 2019, 39, 4814-4828. [CrossRef] [PubMed]

33. Yoo, H.J.; Cho, I.H.; Park, M.; Yang, S.Y.; Kim, S.A. Family based association of GRIN2A and GRIN2B with Korean autism spectrum disorders. Neurosci. Lett. 2012, 512, 89-93. [CrossRef] [PubMed]

34. Tarabeux, J.; Kebir, O.; Gauthier, J.; Hamdan, F.F.; Xiong, L.; Piton, A.; Spiegelman, D.; Henrion, É.; Millet, B.; Fathalli, F.; et al. Rare mutations in N-methyl-D-aspartate glutamate receptors in autism spectrum disorders and schizophrenia. Transl. Psychiatry 2011, 1, e55. [CrossRef]

35. Kouser, M.; Speed, H.E.; Dewey, C.M.; Reimers, J.M.; Widman, A.J.; Gupta, N.; Liu, S.; Jaramillo, T.C.; Bangash, M.; Xiao, B.; et al. Loss of predominant Shank3 isoforms results in hippocampus-dependent impairments in behavior and synaptic transmission. J. Neurosci. 2013, 33, 18448-18468. [CrossRef] [PubMed]

36. Tabuchi, K.; Blundell, J.; Etherton, M.R.; Hammer, R.E.; Liu, X.; Powell, C.M.; Südhof, T.C. A neuroligin-3 mutation implicated in autism increases inhibitory synaptic transmission in mice. Science 2007, 318, 71-76. [CrossRef]

37. Soda, T.; Mapelli, L.; Locatelli, F.; Botta, L.; Goldfarb, M.; Prestori, F.; D’Angelo, E. Hyperexcitability and hyperplasticity disrupt cerebellar signal transfer in the IB2 KO mouse model of autism. J. Neurosci. 2019, 39, 2383-2397.

38. Chung, C.; Ha, S.; Kang, H.; Lee, J.; Um, S.M.; Yan, H.; Yoo, Y.E.; Yoo, T.; Jung, H.; Lee, D.; et al. Early correction of N-methyl-D-aspartate receptor function improves autistic-like social behaviors in adult Shank2-/- mice. Biol. Psychiatry 2019, 85, 534-543. [CrossRef]

39. Mehta, M.V.; Gandal, M.J.; Siegel, S.J. mGluR5-antagonist mediated reversal of elevated stereotyped, repetitive behaviors in the VPA model of autism. PLOS ONE 2011, 6, e26077. [CrossRef]

40. Won, H.; Lee, H.R.; Gee, H.Y.; Mah, W.; Kim, J.I.; Lee, J.; Ha, S.; Chung, C.; Jung, E.S.; Cho, Y.S.; et al. Autistic-like social behaviour in Shank2-mutant mice improved by restoring NMDA receptor function. Nature 2012, 486, 261. [CrossRef]

41. Marro, S.G.; Chanda, S.; Yang, N.; Janas, J.A.; Valperga, G.; Trotter, J.; Zhou, B.; Merrill, S.; Yousif, I.; Shelby, H.; et al. Neuroligin-4 regulates excitatory synaptic transmission in human neurons. Neuron 2019, 103, 617-626. [CrossRef]

42. Krishnan, V.; Stoppel, D.C.; Nong, Y.; Johnson, M.A.; Nadler, M.J.; Ozkaynak, E.; Teng, B.L.; Nagakura, I.; Mohammad, F.; Silva, M.A.; et al. Autism gene Ube3a and seizures impair sociability by repressing VTA Cbln1. Nature 2017, 543, 507-512. [CrossRef] [PubMed]

43. Trobiani, L.; Favaloro, F.L.; Di Castro, M.A.; Di Mattia, M.; Cariello, M.; Miranda, E.; Canterini, S.; De Stefano, M.E.; Comoletti, D.; Limatola, C.; et al. UPR activation specifically modulates glutamate neurotransmission in the cerebellum of a mouse model of autism. Neurobiol. Dis. 2018, 120, 139-150. [CrossRef] [PubMed]

44. Naaijen, J.; Bralten, J.; Poelmans, G.; Glennon, J.C.; Franke, B.; Buitelaar, J.K. Glutamatergic and GABAergic gene sets in attention-deficit/hyperactivity disorder: Association to overlapping traits in ADHD and autism. Transl. Psychiatry 2017, 7, e999. [CrossRef] [PubMed]

45. Lee, E.J.; Choi, S.Y.; Kim, E. NMDA receptor dysfunction in autism spectrum disorders. Curr. Opin. Pharmacol. 2015, 20, 8-13. [CrossRef] [PubMed] 
46. Urbano, M.; Okwara, L.; Manser, P.; Hartmann, K.; Herndon, A.; Deutsch, S.I. A trial of D-cycloserine to treat stereotypies in older adolescents and young adults with autism spectrum disorder. Clin. Neuropharmacol. 2014, 37, 69. [CrossRef]

47. Posey, D.J.; Kem, D.L.; Swiezy, N.B.; Sweeten, T.L.; Wiegand, R.E.; McDougle, C.J. A pilot study of D-cycloserine in subjects with autistic disorder. Am. J. Psychiatry 2004, 161, 2115-2117. [CrossRef]

48. Hosenbocus, S.; Chahal, R. Memantine: A review of possible uses in child and adolescent psychiatry. J. Can. Acad. Child Adolesc. Psychiatry 2013, 22, 166.

49. Hosenbocus, S.; Chahal, R. Amantadine: A review of use in child and adolescent psychiatry. J. Can. Acad. Child Adolesc. Psychiatry 2013, 22, 55.

50. Yang, C.J.; Tan, H.P.; Du, Y.J. The developmental disruptions of serotonin signaling may involved in autism during early brain development. Neuroscience 2014, 267, 1-10. [CrossRef]

51. Celada, P.; Puig, M.; Artigas, F. Serotonin modulation of cortical neurons and networks. Front. Integr. Neurosci. 2013, 7, 25. [CrossRef]

52. Gaspar, P.; Cases, O.; Maroteaux, L. The developmental role of serotonin: News from mouse molecular genetics. Nat. Rev. Neurosci. 2003, 4, 1002-1012. [CrossRef] [PubMed]

53. Jenkins, T.A.; Nguyen, J.C.; Polglaze, K.E.; Bertrand, P.P. Influence of tryptophan and serotonin on mood and cognition with a possible role of the gut-brain axis. Nutrients 2016, 8, 56. [CrossRef] [PubMed]

54. Rose'Meyer, R. A review of the serotonin transporter and prenatal cortisol in the development of autism spectrum disorders. Mol. Autism 2013, 4, 37. [CrossRef] [PubMed]

55. Muller, C.L.; Anacker, A.M.; Veenstra-VanderWeele, J. The serotonin system in autism spectrum disorder: From biomarker to animal models. Neuroscience 2016, 321, 24-41. [CrossRef]

56. Siemann, J.K.; Muller, C.L.; Forsberg, C.G.; Blakely, R.D.; Veenstra-VanderWeele, J.; Wallace, M.T. An autism-associated serotonin transporter variant disrupts multisensory processing. Transl. Psychiatry 2017, 7, e1067. [CrossRef]

57. Abdulamir, H.A.; Abdul-Rasheed, O.F.; Abdulghani, E.A. Serotonin and serotonin transporter levels in autistic children. Saudi Med. J. 2018, 39, 487. [CrossRef]

58. Chugani, D.C.; Muzik, O.; Behen, M.; Rothermel, R.; Janisse, J.J.; Lee, J.; Chugani, H.T. Developmental changes in brain serotonin synthesis capacity in autistic and nonautistic children. Ann. Neurol. Off. J. Am. Neurol. Assoc. Child Neurol. Soc. 1999, 45, 287-295. [CrossRef]

59. Hwang, B.J.; Mohamed, M.A.; Brašić, J. Molecular imaging of autism spectrum disorder. Int. Rev. Psychiatry 2017, 29, 530-554. [CrossRef]

60. Lesch, K.P.; Wolozin, B.L.; Murphy, D.L.; Riederer, P. Primary structure of the human platelet serotonin uptake site: Identity with the brain serotonin transporter. J. Neurochem. 1993, 60, 2319-2322. [CrossRef]

61. Jaiswal, P.; Guhathakurta, S.; Singh, A.S.; Verma, D.; Pandey, M.; Varghese, M.; Sinha, S.; Ghosh, S.; Mohanakumar, K.P.; Rajamma, U. SLC6A4 markers modulate platelet 5-HT level and specific behaviors of autism: A study from an Indian population. Prog. Neuro-Psychopharmacol. Biol. Psychiatry 2015, 56, 196-206. [CrossRef]

62. Sjaarda, C.P.; Hecht, P.; McNaughton, A.J.M.; Zhou, A.; Hudson, M.L.; Will, M.J.; Smith, G.; Ayub, M.; Liang, P.; Chen, N.; et al. Interplay between maternal Slc6a4 mutation and prenatal stress: A possible mechanism for autistic behavior development. Sci. Rep. 2017, 7, 1-12. [CrossRef] [PubMed]

63. Anderson, G.M.; Horne, W.C.; Chatterjee, D.; Cohen, D.J. The Hyperserotonemia of Autism a. Ann. N. Y. Acad. Sci. 1990, 600, 331-340. [CrossRef] [PubMed]

64. Anderson, G.M. Genetics of childhood disorders: XLV. Autism, part 4: Serotonin in autism. J. Am. Acad. Child Adolesc. Psychiatry 2002, 41, 1513-1516. [CrossRef] [PubMed]

65. Gabriele, S.; Sacco, R.; Persico, A.M. Blood serotonin levels in autism spectrum disorder: A systematic review and meta-analysis. Eur. Neuropsychopharmacol. 2014, 24, 919-929. [CrossRef] [PubMed]

66. McBride, P.A.; Anderson, G.M.; Hertzig, M.E.; Snow, M.E.; Thompson, S.M.; Khait, V.D.; Shapiro, T.; Cohen, D.J. Effects of diagnosis, race, and puberty on platelet serotonin levels in autism and mental retardation. J. Am. Acad. Child Adolesc. Psychiatry 1998, 37, 767-776. [CrossRef] [PubMed]

67. Mulder, E.J.; Anderson, G.M.; Kema, I.P.; De Bildt, A.; Van Lang, N.D.; Den Boer, J.A.; Minderaa, R.B. Platelet serotonin levels in pervasive developmental disorders and mental retardation: Diagnostic group differences, within-group distribution, and behavioral correlates. J. Am. Acad. Child Adolesc. Psychiatry 2004, 43, 491-499. [CrossRef] 
68. West, L.; Brunssen, S.H.; Waldrop, J. Review of the evidence for treatment of children with autism with selective serotonin reuptake inhibitors. J. Spec. Pediatric Nurs. 2009, 14, 183-191. [CrossRef]

69. Vecchio, D.; Salzano, E.; Vecchio, A.; Roccella, M. A rare unbalanced translocation 1; 18 in a child with epilepsy, mild dysmorphology and mental retardation. Min. Pediatrica 2012, 64, 365-367.

70. Tidey, J.W.; Miczek, K.A. Social defeat stress selectively alters mesocorticolimbic dopamine release: An in vivo microdialysis study. Brain Res. 1996, 721, 140-149. [CrossRef]

71. Dichter, G.S.; Damiano, C.A.; Allen, J.A. Reward circuitry dysfunction in psychiatric and neurodevelopmental disorders and genetic syndromes: Animal models and clinical findings. J. Neurodev. Disord. 2012, 4, 19. [CrossRef]

72. Ernst, M.; Zametkin, A.J.; Matochik, J.A.; Pascualvaca, D.; Cohen, R.M. Low medial prefrontal dopaminergic activity in autistic children. Lancet 1997, 350, 638. [CrossRef]

73. Chevallier, C.; Kohls, G.; Troiani, V.; Brodkin, E.S.; Schultz, R.T. The social motivation theory of autism. Trends Cogn. Sci. 2012, 16, 231-239. [CrossRef] [PubMed]

74. Pavăl, D. A dopamine hypothesis of autism spectrum disorder. Dev. Neurosci. 2017, 39, 355-360. [CrossRef] [PubMed]

75. Lewis, M.H.; Tanimura, Y.; Lee, L.W.; Bodfish, J.W. Animal models of restricted repetitive behavior in autism. Behav. Brain Res. 2007, 176, 66-74. [CrossRef] [PubMed]

76. Presti, M.F.; Mikes, H.M.; Lewis, M.H. Selective blockade of spontaneous motor stereotypy via intrastriatal pharmacological manipulation. Pharmacol. Biochem. Behav. 2003, 74, 833-839. [CrossRef]

77. Gunaydin, L.A.; Grosenick, L.; Finkelstein, J.C.; Kauvar, I.V.; Fenno, L.E.; Adhikari, A.; Lammel, S.; Mirzabekov, J.J.; Airan, R.D.; Zalocusky, K.A.; et al. Natural neural projection dynamics underlying social behavior. Cell 2014, 157, 1535-1551. [CrossRef]

78. Staal, W.G. Autism, DRD3 and repetitive and stereotyped behavior, an overview of the current knowledge. Eur. Neuropsychopharmacol. 2015, 25, 1421-1426. [CrossRef]

79. Staal, W.G.; Langen, M.; Van Dijk, S.; Mensen, V.T.; Durston, S. DRD3 gene and striatum in autism spectrum disorder. Br. J. Psychiatry 2015, 206, 431-432. [CrossRef]

80. Gadow, K.D.; DeVincent, C.J.; Olvet, D.M.; Pisarevskaya, V.; Hatchwell, E. Association of DRD4 polymorphism with severity of oppositional defiant disorder, separation anxiety disorder and repetitive behaviors in children with autism spectrum disorder. Eur. J. Neurosci. 2010, 32, 1058-1065. [CrossRef]

81. DiCarlo, G.E.; Aguilar, J.I.; Matthies, H.J.; Harrison, F.E.; Bundschuh, K.E.; West, A.; Hashemi, P.; Herborg, F.; Rickhag, M.; Chen, H.; et al. Autism-linked dopamine transporter mutation alters striatal dopamine neurotransmission and dopamine-dependent behaviors. J. Clin. Investig. 2019, 129, 3407-3419. [CrossRef] [PubMed]

82. Gadow, K.D.; Pinsonneault, J.K.; Perlman, G.; Sadee, W. Association of dopamine gene variants, emotion dysregulation and ADHD in autism spectrum disorder. Res. Dev. Disabil. 2014, 35, 1658-1665. [CrossRef] [PubMed]

83. Bariselli, S.; Tzanoulinou, S.; Glangetas, C.; Prévost-Solié, C.; Pucci, L.; Viguié, J.; Bezzi, P.; O'Connor, E.C.; Georges, F.; Lüscher, C.; et al. SHANK3 controls maturation of social reward circuits in the VTA. Nat. Neurosci. 2016, 19, 926. [CrossRef] [PubMed]

84. Marcus, R.N.; Owen, R.; Kamen, L.; Manos, G.; McQuade, R.D.; Carson, W.H.; Aman, M.G. A placebo-controlled, fixed-dose study of aripiprazole in children and adolescents with irritability associated with autistic disorder. J. Am. Acad. Child Adolesc. Psychiatry 2009, 48, 1110-1119. [CrossRef] [PubMed]

85. McDougle, C.J.; Scahill, L.; Aman, M.G.; McCracken, J.T.; Tierney, E.; Davies, M.; Arnold, L.E.; Posey, D.J.; Martin, A.; Ghuman, J.K.; et al. Risperidone for the core symptom domains of autism: Results from the study by the autism network of the research units on pediatric psychopharmacology. Am. J. Psychiatry 2005, 162, 1142-1148. [CrossRef]

86. Perry, E.K.; Lee, M.L.; Martin-Ruiz, C.M.; Court, J.A.; Volsen, S.G.; Merrit, J.; Folly, E.; Iversen, P.E.; Bauman, M.L.; Perry, R.H.; et al. Cholinergic activity in autism: Abnormalities in the cerebral cortex and basal forebrain. Am. J. Psychiatry 2001, 158, 1058-1066. [CrossRef]

87. Martin-Ruiz, C.M.; Lee, M.; Perry, R.H.; Baumann, M.; Court, J.A.; Perry, E.K. Molecular analysis of nicotinic receptor expression in autism. Mol. Brain Res. 2004, 123, 81-90. [CrossRef]

88. Lee, M.; Martin-Ruiz, C.; Graham, A.; Court, J.; Jaros, E.; Perry, R.; Iversen, P.; Bauman, M.; Perry, E. Nicotinic receptor abnormalities in the cerebellar cortex in autism. Brain 2002, 125, 1483-1495. [CrossRef] 
89. Wang, L.; Almeida, L.E.; Spornick, N.A.; Kenyon, N.; Kamimura, S.; Khaibullina, A.; Nouraie, M.; Quezado, Z.M. Modulation of social deficits and repetitive behaviors in a mouse model of autism: The role of the nicotinic cholinergic system. Psychopharmacology 2015, 232, 4303-4316. [CrossRef]

90. Takechi, K.; Suemaru, K.; Kiyoi, T.; Tanaka, A.; Araki, H. The $\alpha 4 \beta 2$ nicotinic acetylcholine receptor modulates autism-like behavioral and motor abnormalities in pentylenetetrazol-kindled mice. Eur. J. Pharmacol. 2016, 775, 57-66. [CrossRef]

91. Léna, C.; Popa, D.; Grailhe, R.; Escourrou, P.; Changeux, J.P.; Adrien, J. ß2-Containing nicotinic receptors contribute to the organization of sleep and regulate putative micro-arousals in mice. J. Neurosci. 2004, 24, 5711-5718. [CrossRef]

92. Ross, S.A.; Wong, J.Y.; Clifford, J.J.; Kinsella, A.; Massalas, J.S.; Horne, M.K.; Scheffer, I.E.; Kola, I.; Waddington, J.L.; Berkovic, S.F.; et al. Phenotypic characterization of an $\alpha 4$ neuronal nicotinic acetylcholine receptor subunit knock-out mouse. J. Neurosci. 2000, 20, 6431-6441. [CrossRef] [PubMed]

93. Yang, T.; Xiao, T.; Sun, Q.; Wang, K. The current agonists and positive allosteric modulators of $\alpha 7 \mathrm{nAChR}$ for CNS indications in clinical trials. Acta Pharm. Sin. B 2017, 7, 611-622. [CrossRef] [PubMed]

94. De Jaco, A.; Bernardini, L.; Rosati, J.; Maria Tata, A. Alpha-7 nicotinic receptors in nervous system disorders: From function to therapeutic perspectives. Cent. Nerv. Syst. Agents Med. Chem. (Former. Curr. Med. Chem. Cent. Nerv. Syst. Agents) 2017, 17, 100-108. [CrossRef] [PubMed]

95. Deutsch, S.I.; Burket, J.A.; Urbano, M.R.; Benson, A.D. The $\alpha 7$ nicotinic acetylcholine receptor: A mediator of pathogenesis and therapeutic target in autism spectrum disorders and Down syndrome. Biochem. Pharmacol. 2015, 97, 363-377. [CrossRef] [PubMed]

96. Yasui, D.H.; Scoles, H.A.; Horike, S.I.; Meguro-Horike, M.; Dunaway, K.W.; Schroeder, D.I.; LaSalle, J.M. 15q11. 2-13.3 chromatin analysis reveals epigenetic regulation of CHRNA7 with deficiencies in Rett and autism brain. Hum. Mol. Genet. 2011, 20, 4311-4323. [CrossRef]

97. Wu, W.L.; Adams, C.E.; Stevens, K.E.; Chow, K.H.; Freedman, R.; Patterson, P.H. The interaction between maternal immune activation and alpha 7 nicotinic acetylcholine receptor in regulating behaviors in the offspring. Brain Behav. Immun. 2015, 46, 192-202. [CrossRef]

98. Ghaleiha, A.; Ghyasvand, M.; Mohammadi, M.R.; Farokhnia, M.; Yadegari, N.; Tabrizi, M.; Hajiaghaee, R.; Yekehtaz, H.; Akhondzadeh, S. Galantamine efficacy and tolerability as an augmentative therapy in autistic children: A randomized, double-blind, placebo-controlled trial. J. Psychopharmacol. 2014, 28, 677-685. [CrossRef]

99. Hardan, A.Y.; Handen, B.L. A retrospective open trial of adjunctive donepezil in children and adolescents with autistic disorder. J. Child Adolesc. Psychopharmacol. 2002, 12, 237-241. [CrossRef]

100. Olincy, A.; Harris, J.G.; Johnson, L.L.; Pender, V.; Kongs, S.; Allensworth, D.; Ellis, J.; Zerbe, G.O.; Leonard, S.; Stevens, K.E.; et al. Proof-of-concept trial of an $\alpha 7$ nicotinic agonist in schizophrenia. Arch. Gen. Psychiatry 2006, 63, 630-638. [CrossRef]

101. Olincy, A.; Blakeley-Smith, A.; Johnson, L.; Kem, W.R.; Freedman, R. Brief report: Initial trial of alpha7-nicotinic receptor stimulation in two adult patients with autism spectrum disorder. J. Autism Dev. Disord. 2016, 46, 3812-3817. [CrossRef]

102. Benarroch, E.E. N-acetylaspartate and N-acetylaspartylglutamate: Neurobiology and clinical significance. Neurology 2008, 70, 1353-1357. [CrossRef] [PubMed]

103. Anglin, R.E.; Mazurek, M.F.; Tarnopolsky, M.A.; Rosebush, P.I. The mitochondrial genome and psychiatric illness. Am. J. Med. Genet. Part B Neuropsychiatr. Genet. 2012, 159, 749-759. [CrossRef] [PubMed]

104. Paslakis, G.; Träber, F.; Roberz, J.; Block, W.; Jessen, F. N-acetyl-aspartate (NAA) as a correlate of pharmacological treatment in psychiatric disorders: A systematic review. Eur. Neuropsychopharmacol. 2014, 24, 1659-1675. [CrossRef] [PubMed]

105. Kleinhans, N.M.; Schweinsburg, B.C.; Cohen, D.N.; Müller, R.A.; Courchesne, E. N-acetyl aspartate in autism spectrum disorders: Regional effects and relationship to fMRI activation. Brain Res. 2007, 1162, 85-97. [CrossRef] [PubMed]

106. Naaijen, J.; Zwiers, M.P.; Forde, N.J.; Williams, S.C.; Durston, S.; Brandeis, D.; Glennon, J.C.; The Tactics Consortium; Franke, B.; Lythgoe, D.J.; et al. Striatal structure and its association with N-Acetylaspartate and glutamate in autism spectrum disorder and obsessive compulsive disorder. Eur. Neuropsychopharmacol. 2018, 28, 118-129. [CrossRef] [PubMed]

107. Ebstein, R.P.; Knafo, A.; Mankuta, D.; Chew, S.H.; San Lai, P. The contributions of oxytocin and vasopressin pathway genes to human behavior. Horm. Behav. 2012, 61, 359-379. [CrossRef] 
108. Hammock, E.A. Developmental perspectives on oxytocin and vasopressin. Neuropsychopharmacology 2015, 40, 24-42. [CrossRef]

109. Insel, T.R. The challenge of translation in social neuroscience: A review of oxytocin, vasopressin, and affiliative behavior. Neuron 2010, 65, 768-779. [CrossRef]

110. Jack, A.; Connelly, J.J.; Morris, J.P. DNA methylation of the oxytocin receptor gene predicts neural response to ambiguous social stimuli. Front. Hum. Neurosci. 2012, 6, 280. [CrossRef]

111. Husarova, V.M.; Lakatosova, S.; Pivovarciova, A.; Babinska, K.; Bakos, J.; Durdiakova, J.; Kubranska, A.; Ondrejka, I.; Ostatnikova, D. Plasma oxytocin in children with autism and its correlations with behavioral parameters in children and parents. Psychiatry Investig. 2016, 13, 174. [CrossRef]

112. Jacob, S.; Brune, C.W.; Carter, C.S.; Leventhal, B.L.; Lord, C.; Cook, E.H., Jr. Association of the oxytocin receptor gene (OXTR) in Caucasian children and adolescents with autism. Neurosci. Lett. 2007, 417, 6-9. [CrossRef] [PubMed]

113. Parker, K.J.; Garner, J.P.; Libove, R.A.; Hyde, S.A.; Hornbeak, K.B.; Carson, D.S.; Liao, C.P.; Phillips, J.M.; Hallmayer, J.F.; Hardan, A.Y. Plasma oxytocin concentrations and OXTR polymorphisms predict social impairments in children with and without autism spectrum disorder. Proc. Natl. Acad. Sci. USA 2014, 111, 12258-12263. [CrossRef] [PubMed]

114. Cataldo, I.; Azhari, A.; Esposito, G. A review of oxytocin and arginine-vasopressin receptors and their modulation of autism spectrum disorder. Front. Mol. Neurosci. 2018, 11, 27. [CrossRef] [PubMed]

115. Zhang, R.; Zhang, H.F.; Han, J.S.; Han, S.P. Genes related to oxytocin and arginine-vasopressin pathways: Associations with autism spectrum disorders. Neurosci. Bull. 2017, 33, 238-246. [CrossRef] [PubMed]

116. Arons, M.H.; Thynne, C.J.; Grabrucker, A.M.; Li, D.; Schoen, M.; Cheyne, J.E.; Boeckers, T.M.; Montgomery, J.M.; Garner, C.C. Autism-associated mutations in ProSAP2/Shank3 impair synaptic transmission and neurexin-neuroligin-mediated transsynaptic signaling. J. Neurosci. 2012, 32, 14966-14978. [CrossRef]

117. Boccuto, L.; Lauri, M.; Sarasua, S.M.; Skinner, C.D.; Buccella, D.; Dwivedi, A.; Orteschi, D.; Collins, J.S.; Zollino, M.; Visconti, P.; et al. Prevalence of SHANK3 variants in patients with different subtypes of autism spectrum disorders. Eur. J. Hum. Genet. 2013, 21, 310-316. [CrossRef]

118. Rajamani, K.T.; Wagner, S.; Grinevich, V.; Harony-Nicolas, H. Oxytocin as a modulator of synaptic plasticity: Implications for neurodevelopmental disorders. Front. Synaptic Neurosci. 2018, 10, 17. [CrossRef]

119. Sala, M.; Braida, D.; Lentini, D.; Busnelli, M.; Bulgheroni, E.; Capurro, V.; Finardi, A.; Donzelli, A.; Pattini, L.; Rubino, T.; et al. Pharmacologic rescue of impaired cognitive flexibility, social deficits, increased aggression, and seizure susceptibility in oxytocin receptor null mice: A neurobehavioral model of autism. Biol. Psychiatry 2011, 69, 875-882. [CrossRef]

120. Bielsky, I.F.; Young, L.J. Oxytocin, vasopressin, and social recognition in mammals. Peptides 2004, 25, 1565-1574. [CrossRef]

121. Wagner, S.; Harony-Nicolas, H. Oxytocin and animal models for autism spectrum disorder. In Behavioral Pharmacology of Neuropeptides: Oxytocin; Springer: Cham, Switzerland, 2017; pp. 213-237.

122. T Tachibana, M.; Kagitani-Shimono, K.; Mohri, I.; Yamamoto, T.; Sanefuji, W.; Nakamura, A.; Oishi, M.; Kimura, T.; Onaka, T.; Ozono, K.; et al. Long-term administration of intranasal oxytocin is a safe and promising therapy for early adolescent boys with autism spectrum disorders. J. Child Adolesc. Psychopharmacol. 2013, 23, 123-127. [CrossRef]

123. Dadds, M.R.; MacDonald, E.; Cauchi, A.; Williams, K.; Levy, F.; Brennan, J. Nasal oxytocin for social deficits in childhood autism: A randomized controlled trial. J. Autism Dev. Disord. 2014, 44, 521-531. [CrossRef] [PubMed]

124. Kosaka, H.; Munesue, T.; Ishitobi, M.; Asano, M.; Omori, M.; Sato, M.; Tomoda, A.; Wada, Y. Long-term oxytocin administration improves social behaviors in a girl with autistic disorder. BMC Psychiatry 2012, 12, 110. [CrossRef] [PubMed]

125. Ooi, Y.P.; Weng, S.J.; Kossowsky, J.; Gerger, H.; Sung, M. Oxytocin and autism spectrum disorders: A systematic review and meta-analysis of randomized controlled trials. Pharmacopsychiatry 2017, 50, 5-13. [CrossRef]

126. Skuse, D.H.; Gallagher, L. Dopaminergic-neuropeptide interactions in the social brain. Trends Cogn. Sci. 2009, 13, 27-35. [CrossRef] [PubMed] 
127. Miano, S.; Bruni, O.; Elia, M.; Trovato, A.; Smerieri, A.; Verrillo, E.; Roccella, M.; Terzano, M.G.; Ferri, R. Sleep in children with autistic spectrum disorder: A questionnaire and polysomnographic study. Sleep Med. 2007, 9, 64-70. [CrossRef]

128. Souders, M.C.; Zavodny, S.; Eriksen, W.; Sinko, R.; Connell, J.; Kerns, C.; Schaaf, R.; Pinto-Martin, J. Sleep in children with autism spectrum disorder. Curr. Psychiatry Rep. 2017, 19, 34. [CrossRef]

129. Galano, A.; Tan, D.X.; Reiter, R.J. Melatonin as a natural ally against oxidative stress: A physicochemical examination. J. Pineal Res. 2011, 51, 1-16. [CrossRef]

130. Bubenik, G.A. Gastrointestinal melatonin: Localization, function, and clinical relevance. Dig. Dis. Sci. 2002, 47, 2336-2348. [CrossRef]

131. Tordjman, S.; Najjar, I.; Bellissant, E.; Anderson, G.M.; Barburoth, M.; Cohen, D.; Jaafari, N.; Schischmanoff, O.; Fagard, R.; Lagdas, E.; et al. Advances in the research of melatonin in autism spectrum disorders: Literature review and new perspectives. Int. J. Mol. Sci. 2013, 14, 20508-20542. [CrossRef]

132. Braam, W.; Ehrhart, F.; Maas, A.P.; Smits, M.G.; Curfs, L. Low maternal melatonin level increases autism spectrum disorder risk in children. Res. Dev. Disabil. 2018, 82, 79-89. [CrossRef]

133. Jin, Y.; Choi, J.; Won, J.; Hong, Y. The relationship between autism spectrum disorder and melatonin during fetal development. Molecules 2018, 23, 198. [CrossRef] [PubMed]

134. Rossignol, D.A.; Frye, R.E. Melatonin in autism spectrum disorders: A systematic review and meta-analysis. Dev. Med. Child Neurol. 2011, 53, 783-792. [CrossRef] [PubMed]

135. Malow, B.A.; Byars, K.; Johnson, K.; Weiss, S.; Bernal, P.; Goldman, S.E.; Panzer, R.; Coury, D.L.; Glaze, D.G.; Sleep Committee of the Autism Treatment Network. A practice pathway for the identification, evaluation, and management of insomnia in children and adolescents with autism spectrum disorders. Pediatrics 2012, 130 (Suppl. S2), S106-S124. [CrossRef] [PubMed]

136. Cuomo, B.M.; Vaz, S.; Lee EA, L.; Thompson, C.; Rogerson, J.M.; Falkmer, T. Effectiveness of sleep-based interventions for children with autism spectrum disorder: A meta-synthesis. Pharmacother. J. Hum. Pharmacol. Drug Ther. 2017, 37, 555-578. [CrossRef] [PubMed]

137. Gagnon, K.; Godbout, R. Melatonin and comorbidities in children with autism spectrum disorder. Curr. Dev. Disord. Rep. 2018, 5, 197-206. [CrossRef]

138. Cherniack, E.P.; AS, B.T.D. Brown AJ, Slatopolsky E. Vitamin D. Am. J. Physiol. Ren. Physiol. 2005, 289, F8-F28.

139. Cui, X.; Gooch, H.; Groves, N.J.; Sah, P.; Burne, T.H.; Eyles, D.W.; McGrath, J.J. Vitamin D and the brain: Key questions for future research. J. Steroid Biochem. Mol. Biol. 2015, 148, 305-309. [CrossRef]

140. Cannell, J.J.; Grant, W.B. What is the role of vitamin D in autism? Derm. Endocrinol. 2013, 5, $199-204$. [CrossRef]

141. Kočovská, E.; Fernell, E.; Billstedt, E.; Minnis, H.; Gillberg, C. Vitamin D and autism: Clinical review. Res. Dev. Disabil. 2012, 33, 1541-1550.

142. Alfawaz, H.A.; Bhat, R.S.; Al-Ayadhi, L.; El-Ansary, A.K. Protective and restorative potency of Vitamin D on persistent biochemical autistic features induced in propionic acid-intoxicated rat pups. BMC Complementary Altern. Med. 2014, 14, 416. [CrossRef]

143. Ali, A.; Cui, X.; Eyles, D. Developmental vitamin D deficiency and autism: Putative pathogenic mechanisms. J. Steroid Biochem. Mol. Biol. 2018, 175, 108-118. [CrossRef] [PubMed]

144. Vinkhuyzen, A.A.E.; Eyles, D.W.; Burne, T.H.J.; Blanken, L.M.E.; Kruithof, C.J.; Verhulst, F.; Jaddoe, V.W.; Tiemeier, H.; McGrath, J.J. Gestational vitamin D deficiency and autism-related traits: The Generation R Study. Mol. Psychiatry 2018, 23, 240-246. [CrossRef] [PubMed]

145. Feng, J.; Shan, L.; Du, L.; Wang, B.; Li, H.; Wang, W.; Wang, T.; Dong, H.; Yue, X.; Xu, Z.; et al. Clinical improvement following vitamin D3 supplementation in autism spectrum disorder. Nutr. Neurosci. 2017, 20, 284-290. [CrossRef] [PubMed]

146. Infante, M.; Sears, B.; Rizzo, A.M.; Mariani Cerati, D.; Caprio, M.; Ricordi, C.; Fabbri, A. Omega-3 PUFAs and vitamin D co-supplementation as a safe-effective therapeutic approach for core symptoms of autism spectrum disorder: Case report and literature review. Nutr. Neurosci. 2018, 1-12. [CrossRef]

147. Cannell, J.J. Vitamin D and autism, what's new? Rev. Endocr. Metab. Disord. 2017, 18, 183-193. [CrossRef]

148. Kerley, C.P.; Power, C.; Gallagher, L.; Coghlan, D. Lack of effect of vitamin D3 supplementation in autism: A 20-week, placebo-controlled RCT. Arch. Dis. Child. 2017, 102, 1030-1036. [CrossRef] 
149. Kukkonen, J.P. Orexin/hypocretin signaling. In Behavioral Neuroscience of Orexin/Hypocretin; Springer: Cham, Switzerland, 2016; pp. 17-50.

150. Chen, Q.; de Lecea, L.; Hu, Z.; Gao, D. The hypocretin/orexin system: An increasingly important role in neuropsychiatry. Med. Res. Rev. 2015, 35, 152-197. [CrossRef]

151. Precenzano, F.; Ruberto, M.; Parisi, L.; Salerno, M.; Maltese, A.; Verde, D.; Tripi, G.; Romano, P.; Folco, A.D.; Filippo, T.D.; et al. Sleep habits in children affected by autism spectrum disorders: A preliminary case-control study. Acta Medica Mediterr. 2017, 33, 405-409.

152. Kohyama, J. Possible neuronal mechanisms of sleep disturbances in patients with autism spectrum disorders and attention-deficit/hyperactivity disorder. Med. Hypotheses 2016, 97, 131-133. [CrossRef]

153. Levitas-Djerbi, T.; Appelbaum, L. Modeling sleep and neuropsychiatric disorders in zebrafish. Curr. Opin. Neurobiol. 2017, 44, 89-93. [CrossRef]

154. Kobylinska, L.; Panaitescu, A.M.; Gabreanu, G.; Anghel, C.G.; Mihailescu, I.; Rad, F.; Nedelcu, C.; Mocanu, I.; Constantin, C.; Badescu, S.V.; et al. Plasmatic levels of neuropeptides, including oxytocin, in children with autism spectrum disorder, correlate with the disorder severity. Acta Endocrinol. (Bucharest) 2019, 5, 16. [CrossRef] [PubMed]

155. Sandman, C.A. The opiate hypothesis in autism and self-injury. J. Child Adolesc. Psychopharmacol. 1991, 1, 237-248. [CrossRef]

156. Sandman, C.A. Various Endogenous Opioids and Autistic Behavior: A Response to Gillberg. J. Dev. Disord. 1992, 22, 132-133. [CrossRef]

157. Tordjman, S.; Anderson, G.M.; McBride, P.A.; Hertzig, M.E.; Snow, M.E.; Hall, L.M.; Thompson, S.M.; Ferrari, P.; Cohen, D.J. Plasma $\beta$-endorphin, adrenocorticotropin hormone, and cortisol in autism. J. Child Psychol. Psychiatry 1997, 38, 705-715. [CrossRef] [PubMed]

158. Gillberg, C.; Hagberg, B.; Witt-Engerstom, I.; Eriksson, I. CSF beta endorphins in childhood neuropsychiatric disorders. Brain Dev. 1990, 12, 92.

159. Tordjman, S.; Anderson, G.M.; Botbol, M.; Brailly-Tabard, S.; Perez-Diaz, F.; Graignic, R.; Carlier, M.; Schmit, G.; Rolland, A.C.; Bonnot, O.; et al. Pain reactivity and plasma $\beta$-endorphin in children and adolescents with autistic disorder. PLoS ONE 2009, 4, e5289. [CrossRef] [PubMed]

160. Bouvard, M.P.; Leboyer, M.; Launay, J.M.; Recasens, C.; Plumet, M.H.; Waller-Perotte, D.; Tabuteau, F.; Bondoux, D.; Dugas, M.; Lensing, P.; et al. Low-dose naltrexone effects on plasma chemistries and clinical symptoms in autism: A double-blind, placebo-controlled study. Psychiatry Res. 1995, 58, 191-201. [CrossRef]

161. Leboyer, M.; Bouvard, M.P.; Launay, J.M.; Tabuteau, F.; Waller, D.; Dugas, M.; Kerdelhue, B.; Lensing, P.; Panksepp, J. Brief report: A double-blind study of naltrexone in infantile autism. J. Autism Dev. Disord. 1992, 22, 309-319. [CrossRef]

162. Roy, A.; Roy, M.; Deb, S.; Unwin, G.; Roy, A. Are opioid antagonists effective in attenuating the core symptoms of autism spectrum conditions in children: A systematic review. J. Intellect. Disabil. Res. 2015, 59, 293-306. [CrossRef]

163. Smirni, D.; Smirni, P.; Carotenuto, M.; Parisi, L.; Quatrosi, G.; Roccella, M. Noli Me Tangere: Social Touch, Tactile Defensiveness, and Communication in Neurodevelopmental Disorders. Brain Sci. 2019, 9, 368. [CrossRef]

164. Carotenuto, M.; Ruberto, M.; Fontana, M.; Catania, A.; Misuraca, E.; Precenzano, F.; Lanzara, V.; Messina, G.; Roccella, M.; Smirni, D. Executive functioning in autism spectrum disorders: A case-control study in preschool children. Curr. Pediatr. Res. 2019, 23, 112-116.

165. Smirni, D.; Precenzano, F.; Magliulo, R.; Romano, P.; Bonifacio, A.; Gison, G.; Bitetti, I.; Terracciano, M.; Ruberto, M.; Sorrentino, M.; et al. Inhibition, set-shifting and working memory in Global Developmental Delay preschool children. Life Span Disabil 2018, 21, 191-206.

166. Smirni, D.; Smirni, P.; Di Martino, G.; Operto, F.F.; Carotenuto, M. Emotional awareness and cognitive performance in borderline intellectual functioning young adolescents. J. Nerv. Ment. Dis. 2019, 207, 365-370. [CrossRef] [PubMed]

(C) 2020 by the authors. Licensee MDPI, Basel, Switzerland. This article is an open access article distributed under the terms and conditions of the Creative Commons Attribution (CC BY) license (http://creativecommons.org/licenses/by/4.0/). 